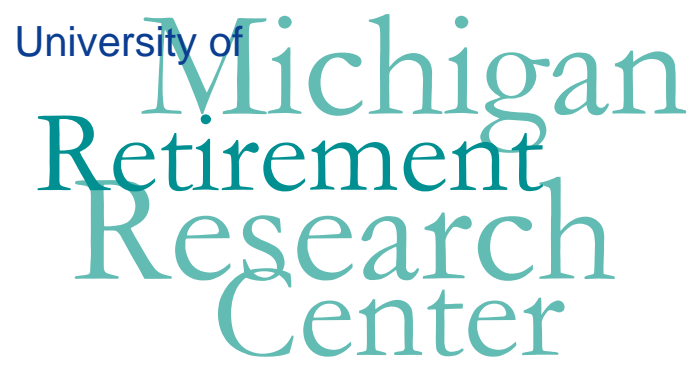

Working Paper WP 2004-087

\title{
Welfare Reform and Immigrant Participation in the Supplemental Security Income Program
}

Paul S. Davies and Michael J. Greenwood

\begin{tabular}{|l|l|}
\hline $\mathrm{M}$ & $\mathrm{R}$ \\
\hline $\mathrm{R}$ & $\mathrm{C}$ \\
\hline
\end{tabular}$\quad$ Project \#: UM02-C1 


\title{
"Welfare Reform and Immigrant Participation in the Supplemental Security Income Program”
}

\author{
Paul S. Davies \\ Social Security Administration \\ Michael J. Greenwood \\ University of Colorado at Boulder
}

September 2004

\author{
Michigan Retirement Research Center \\ University of Michigan \\ P.O. Box 1248 \\ Ann Arbor, MI 48104
}

\section{Acknowledgements}

This work was supported by a grant from the Social Security Administration through the Michigan Retirement Research Center (Grant \# 10-P-98358-5). The opinions and conclusions are solely those of the authors and should not be considered as representing the opinions or policy of the Social Security Administration or any agency of the Federal Government.

\section{Regents of the University of Michigan}

David A. Brandon, Ann Arbor; Laurence B. Deitch, Bingham Farms; Olivia P. Maynard, Goodrich; Rebecca McGowan, Ann Arbor; Andrea Fischer Newman, Ann Arbor; Andrew C. Richner, Grosse Pointe Park; S. Martin Taylor, Gross Pointe Farms; Katherine E. White, Ann Arbor; Mary Sue Coleman, ex officio 


\title{
Welfare Reform and Immigrant Participation in the Supplemental Security Income Program
}

\author{
Paul S. Davies and Michael J. Greenwood
}

\begin{abstract}
We examine the effect of the 1996 welfare reform legislation on participation in the Supplemental Security Income (SSI) program by immigrants. Although none of the immigrants on the SSI rolls before welfare reform lost eligibility, the potential exists for future impacts on the SSI caseload and the well-being of recent immigrants. We use microdata files from the Social Security Administration's Continuous Work History Sample matched to administrative data on SSI participation for the period 1993 to 1999. We estimate simple models of SSI participation and compare our results to the existing literature. We then estimate a series of difference-in-differences models of SSI participation. These models compare SSI participation by immigrants relative to nativeborn individuals, and among affected immigrants relative to unaffected immigrants and native-born individuals, before and after welfare reform. Descriptive results indicate that the percentage of immigrants and natives receiving SSI decreased after welfare reform, but by a larger percentage for natives than for immigrants. The probability of

SSI participation decreased after welfare reform for immigrants who were affected by the legislation relative to immigrants who were unaffected. The difference-in-differences estimate is positive for immigrants relative to otherwise similar natives, but the estimated effect among affected immigrants is about half as large as the effect for unaffected immigrants. When the sample is limited to low earners as a proxy for the SSI means test, the results are qualitatively unchanged but quantitatively much stronger.
\end{abstract}

\section{Authors' Acknowledgements}

We are grateful to Ulyses Balderas for assisting with the collection of some data used here. A previous version of this paper was presented at the 2004 Western Regional Science Association Annual Meeting, February 25-28, 2004, Maui, HI. 


\section{Introduction}

Taxes and transfers are potentially important channels through which redistributions occur from natives to immigrants. An important issue that arises in this context involves immigrant participation in welfare programs. Although some evidence suggests that immigrants, especially more recent immigrants, are less likely to participate in welfare programs than otherwise comparable natives (Borjas and Trejo, 1991; Blau, 1984; Tienda and Jensen, 1986), significant transfers from natives to immigrants still may occur. In the United States, two of the most important welfare programs that involve the foreign born are the Temporary Assistance for Needy Families (TANF, formerly Aid for Families with Dependent Children or AFDC) and Supplemental Security Income (SSI) programs. Some evidence suggests that immigrant participation in social welfare programs rises with duration of residence in the United States (Blau, 1984), and this tendency should be particularly marked for SSI, one component of which provides benefits specifically for older persons. Partially in response to immigrant usage of welfare, in 1996 the U.S. Congress implemented welfare reforms that limited the access of noncitizens to welfare. The present study, which specifically concerns SSI, seeks to determine how successful Congress was in forbidding or discouraging foreign-born participation in this program.

Congress established the SSI program in 1972, and the program actually began making payments in January, 1974. This means-tested program was to provide cash assistance to needy aged, blind, and disabled citizens and noncitizens lawfully admitted for permanent residence or permanently residing under color of law. Between 1974 and the present, the program underwent many changes that affected the eligibility of noncitizens, and participation by noncitizens changed dramatically. Both the absolute number of immigrants receiving SSI benefits and the 
number of immigrants receiving SSI benefits as a percentage of all SSI recipients increased substantially between 1982 and 1995. This is particularly true among the elderly. In 1982, 127,900 SSI recipients were non-citizen immigrants, representing 3.3 percent of the total caseload. By 1995, 785,410 SSI recipients, or 12.1 percent of the caseload, were non-citizen immigrants. Among elderly SSI recipients, 91,900 (5.9 percent) were non-citizen immigrants in 1982, compared to 459,220 (31.8 percent) in 1995 (Parrott, Kennedy, and Scott, 1998). The average federally administered SSI payment to non-citizens in December 1995 was $\$ 422$, compared to $\$ 309$ for citizens (Social Security Administration, 1996, Table 5). Given that U.S. immigration law has a strong family reunification component, the age composition of immigrants to the U.S. is becoming increasingly older, and the skill composition is becoming increasingly less skilled (Greenwood and McDowell, 1999), many expected that the upward trend in the proportion of SSI recipients who are immigrants would continue.

In August, 1996, the Personal Responsibility and Work Opportunity Reconciliation Act (PRWORA) was signed into law. PRWORA, also referred to as welfare reform, substantially limited the eligibility of immigrants for SSI benefits and benefits from other social programs. The Illegal Immigration Reform and Immigrant Responsibility Act of 1996 further restricted immigrant access to the SSI program and strengthened provisions for sponsor-to-immigrant deeming of income in determining SSI eligibility. The Balanced Budget Act of 1997 and subsequent legislation enacted in 1998 restored SSI eligibility to many groups of immigrants, but some are still denied access. Parrott, Kennedy, and Scott (1998) provide a detailed legislative history of the debate surrounding SSI eligibility for immigrants.

Generally speaking, immigrant eligibility for the SSI program includes only non-citizens who were lawfully in the United States as of August 22, 1996, and who were receiving SSI 
benefits on August 22, 1996. Refugees and asylees who entered the United States after August 22, 1996, may be eligible for SSI under current law, but face a 7-year time limit on their eligibility. Other non-citizens who entered the U.S. after August 22, 1996, may become eligible for SSI only by becoming U.S. citizens or by amassing 40 quarters of Social Security-covered employment. All immigrants who apply for SSI benefits are subject to strict and legally enforceable provisions regarding sponsor-to-immigrant deeming.

Although none of the non-citizens on the SSI rolls prior to August 22, 1996, lost SSI eligibility as a result of the legislative changes, the potential exists for substantial future impacts on SSI caseloads and program costs and on the well-being of recent immigrants themselves. Even among those non-citizens who are eligible for SSI, there may have been a "chilling effect" from the legislative changes (Fix and Passel, 1999), resulting in a decrease in the SSI application rate. In addition, low-income and disabled non-citizens now have an incentive to become U.S. citizens in order to become eligible for SSI benefits. Indeed, in 1996 and subsequent years the number of naturalizations increased significantly. Borjas (2002) found a strong positive correlation between pre-welfare reform welfare utilization and post-welfare reform naturalization rates.

It is well known that the AFDC/TANF caseload decreased substantially in the years immediately following passage of the welfare reform legislation. The extent to which this decline is due to welfare reform or the strong economic growth experienced during the 1990s is the subject of much debate (Council of Economic Advisors, 1997; Moffitt, 1999; Figlio and Ziliak, 1999; Haider, Klerman, and Roth, 2003). Some studies based on publicly-available survey data also cite a decline in the percentage of households receiving SSI in the years after welfare reform (Borjas, 2002; Fix and Passel, 2002). Our descriptive analyses based on 
individual-level data from the Social Security Administration (SSA) confirm these previous findings. The percentage of immigrants receiving SSI decreased by about 5.5 percent between the pre-welfare reform period (1993 to 1995) and the post-welfare reform period (1997 to 1999). Importantly, however, the percentage of native-born individuals receiving SSI decreased by approximately 9.5 percent over that same period. Moreover, the absolute number of noncitizens receiving SSI increased each year from 1997 to 2002, after an initial drop between 1996 and 1997 (Social Security Administration, 2003).

In the analysis that follows, using administrative data sources from SSA, we estimate models of SSI participation by immigrants in years prior to welfare reform and in years since welfare reform. Results for the pre-reform and post-reform years are contrasted to identify changes in the underlying relationship between immigrant characteristics and SSI participation. Changes in participation outcomes may be the result of changes in the laws (e.g., welfare reform legislation) or program rules, changes in the (age, sex, skill, source country) composition of the immigrant population, and changes in economic conditions. We attempt to isolate the effect of changes in the law through the use of difference-in-differences models of the probability of SSI participation.

In the next section, we discuss the data used in this study. Subsequent sections describe the models and methodology employed here, as well as the empirical results. The final section provides a summary and conclusions.

\section{Data}

Prior studies of welfare receipt among immigrants have relied on decennial Census data (e.g., Bean, Van Hook, and Glick, 1997; Borjas and Trejo, 1993). However, Bean and Van 
Hook (1996-97) note several problems regarding the use of decennial Census data to study the two most common welfare programs (AFDC, now TANF, and SSI). Van Hook, Bean, and Glick (1996) suggest several corrections to such data to make them better correspond to information from administrative records. As noted by these authors and others, one of the most important advantages of decennial Census data is that the number of observations is great, which allows more detailed analyses, such as by country of birth.

The data that underlie our study are derived from administrative records themselves. Our samples, which contain about 3 million records (with about half of these for the foreign born) randomly selected from Social Security files, contain sufficient observations to allow detailed analyses both by country of birth and entry cohort. Moreover, one of the major strengths of the data is that they have a temporal component that is lacking in decennial Census data, which provide information on sources of income (e.g., AFDC, SSI) only for the full year preceding the Census. Because the data used here are annual, they allow us to develop observations for just before and just after welfare reform. Since welfare reform occurred in 1996, we focus on the three years before (1993-1995) and the three years after (1997-1999).

Relative to decennial Census data, administrative data are characterized by certain shortcomings. The most important of these for our purposes is that they do not contain detailed economic, social, and demographic information. For example, the data contain no information on education, health status, marital status, or family composition. This is not to say that the data contain no socio-economic information. Social Security records provide age, sex, and annual compensation (up to the Social Security maximum for contribution purposes).

The SSA administrative records that we use are drawn from the one-percent Continuous Work History Sample (CWHS), which has been matched to the Social Security number 
identification file. Using these data, we develop a longitudinal sample of immigrants and natives prior to welfare reform and since welfare reform. Place of birth codes on the Social Security number identification file allow for the identification of country of birth. Date of establishment of the Social Security number (SSN) is used as a proxy for year of entry into the United States. The CWHS provides annual earnings for each individual by employer, major industry codes, and geography (employer-based prior to 1994, employee-residence-based starting in 1994).

To the CWHS-based file is matched a longitudinal extract from the Supplemental Security Record that identifies monthly SSI participation and benefit amounts from the inception of the SSI program in January 1974 to the present. The Supplemental Security Record also provides monthly SSI-countable earned and unearned income for SSI applicants and beneficiaries. The number of observations in the analysis file supports detailed analyses of immigrant SSI participation by year, country of birth, year of entry, age, and sex.

To account for local economic and policy conditions, we add data on state unemployment rates, state poverty rates, earnings per worker, state supplementation of federal SSI benefits, implementation of AFDC waivers, implementation of the TANF program, the maximum state AFDC/TANF benefit for a family of three, and the generosity of state programs for immigrants. State poverty rates and earnings per worker are from the Bureau of Economic Analysis Regional Accounts Data. State unemployment rates are from the Bureau of Labor Statistics. Data on the dates of implementation of AFDC waivers and the TANF program are from Crouse (1999). AFDC and TANF benefit levels and SSI state supplements are from various issues of the Green Book. States are classified as more or less generous based on the index developed by the Urban Institute on the availability of state safety net programs for immigrants (Zimmermann and Tumlin, 1999, Table 18). 


\section{Models and Methodology}

We estimate two types of models: (1) basic SSI participation models with controls for immigrant status, and (2) difference-in-differences models that compare SSI participation by immigrants and natives, before and after welfare reform. In the difference-in-differences models, we separately identify immigrants whose potential SSI eligibility was affected by welfare reform and those whose potential SSI eligibility was not affected by welfare reform.

A series of basic SSI participation models are estimated and compared to the existing literature. These models take the form:

$$
\begin{gathered}
P_{i}^{*}=\alpha_{0}+\alpha_{1 j} X_{i j}+\alpha_{2 k} Y_{i k}+\alpha_{3 l} F_{i m}+\alpha_{4} T+\varepsilon_{i} \\
P_{i}=1 \text { if } P_{i}^{*}>0, \text { and } \\
P_{i}=0 \text { if } P_{i}^{*} \leq 0 .
\end{gathered}
$$

$\mathrm{P}_{\mathrm{i}}$ indicates SSI participation by individual $\mathrm{i}$ (or not); $\mathrm{X}_{\mathrm{ij}}$ is a vector of individual economic and demographic characteristics (e.g., age, gender, earnings); $\mathrm{Y}_{\mathrm{ik}}$ is a vector of economic and policy conditions (e.g., unemployment rate, poverty rate, SSI state supplement, implementation of AFDC waivers, implementation of the TANF program, maximum AFDC/TANF benefit for a family of three, and generosity of programs for immigrants) in the state of residence; $F_{i m}$ is a vector of immigrant status variables (country of birth and year of entry); and, $\mathrm{T}$ is a fixed effect for the year of observation (1993 to 1999).

We also estimate difference-in-differences models that exploit both variation over time (pre-welfare reform and post-welfare reform) and between immigrants and natives to identify the effect of welfare reform on SSI participation by immigrants. The general form of the differencein-differences model is: 


$$
\begin{aligned}
P_{i}= & \beta_{0}+\beta_{1 j} X_{i j}+\beta_{2 k} Y_{i k}+\beta_{3} F B_{i}+\beta_{4} \text { POSTWR }_{i}+ \\
& \beta_{5}\left(F B_{i} * \operatorname{POSTWR}_{i}\right)+\varepsilon_{i}
\end{aligned}
$$

where FB is a dummy variable for immigrant status and POSTWR is a dummy variable indicating post-welfare reform periods. All other variables are as previously defined. In this model, native-born individuals are compared to all foreign-born individuals and the coefficient $\beta_{5}$ is the difference-in-differences estimator. This is a naïve model, however, in that it ignores the distinction between foreign-born individuals whose potential SSI eligibility was affected by welfare reform and those whose potential eligibility was not affected. As discussed earlier, foreign-born individuals who were in the U.S. and receiving SSI benefits as of August 22, 1996, were not affected by the welfare reform legislation. In addition, refugees and asylees remain potentially eligible for SSI benefits for the first seven years after entering the U.S.

Using data on the country of birth and date of entry into the U.S. (date of establishment of SSN) from the Social Security number identification file and receipt of SSI benefits from the Supplemental Security Record, we identify immigrants who were in the U.S. and receiving SSI benefits in 1996. These immigrants are unaffected by the welfare reform legislation. Again using country of birth and year of entry, relative to the year of observation, we identify refugees who have been in the U.S. for less than 7 years. These immigrants also are unaffected by the welfare reform legislation. For this purpose, we assume that all immigrants from the main refugee-sending countries - Russia and the former Soviet Union, Cuba, Bosnia, Iran, Vietnam, Somalia, and Iraq - are refugees. Borjas (2002) uses a similar method to identify refugees. All other immigrants not included in the groups described above are assumed to be affected by the welfare reform legislation. 
We estimate three additional specifications of the difference-in-differences model to exploit the distinction between affected and unaffected immigrants. In equation (3), we examine the difference between affected cases (AFFECTED=1) and unaffected cases (AFFECTED=0), in the post-reform period relative to the pre-reform period.

$$
\begin{aligned}
P_{i}= & \gamma_{0}+\gamma_{1 j} X_{i j}+\gamma_{2 k} Y_{i k}+\gamma_{3} \text { AFFECTED }_{i}+\gamma_{4} \text { POSTWR }_{i}+ \\
& \gamma_{5}\left(\text { AFFECTED }_{i} * \text { POSTWR }_{i}\right)+\varepsilon_{i}
\end{aligned}
$$

The difference-in-differences estimator is $\gamma_{5}$. When we limit the sample to foreign-born individuals, the comparison is between affected immigrants and unaffected immigrants. In this case, we expect $\gamma_{3}$ to be negative, indicating a lower probability of SSI participation among affected immigrants relative to unaffected immigrants in the post-reform period relative to the pre-reform period. When we use the full sample of native-born and foreign-born individuals, the difference-in-difference estimator provides a comparison between affected foreign-born individuals and all unaffected individuals, including both the native born and unaffected foreign born.

Finally, in equation (4), we use the full sample of native-born and foreign-born individuals and separately identify native-born individuals $(\mathrm{NB}=1)$, affected foreign-born individuals $(\mathrm{NB}=0$ and $\mathrm{AFFECTED}=1)$, and unaffected foreign-born individuals $(\mathrm{NB}=0$ and AFFECTED $=0$ ).

$$
\begin{aligned}
P_{i}= & \delta_{0}+\delta_{1 j} X_{i j}+\delta_{2 k} Y_{i k}+\delta_{3} \text { AFFECTED }_{i}+\delta_{4} N B_{i}+\delta_{5} \text { POSTWR }_{i}+ \\
& \delta_{6}\left(\text { AFFECTED }_{i} * \text { POSTWR }_{i}\right)+\delta_{7}\left(N B_{i} * \text { POSTWR }_{i}\right)+\varepsilon_{i}
\end{aligned}
$$

From this model, we calculate three difference-in-differences effects. The difference-indifferences estimator for affected foreign-born individuals relative to unaffected foreign-born individuals is $\delta_{6}$. The estimator for affected foreign-born individuals relative to native-born 
individuals is $\left(\delta_{6}-\delta_{7}\right)$. Finally, the difference-in-differences estimator for unaffected foreignborn individuals relative to native-born individuals is $-\delta_{7}$.

All of the models described above ignore the fact that SSI is a means-tested program. In other words, many of the individuals in our sample will be ineligible to participate because their income and/or assets exceed the SSI eligibility thresholds. Although we cannot precisely measure SSI financial eligibility with our data, we create a rough proxy by calculating the maximum annual earnings that would be consistent with SSI income eligibility, assuming zero unearned income. We then limit our sample to those individuals with earnings below this threshold (i.e., the low earner sample) and re-estimate equations (1) through (4). The results are discussed in the following section.

\section{Empirical Results}

Table 1 contains definitions of all variables used in this study, along with their means and standard deviations. The full sample consists of about 3 million native-born and foreign-born individuals for the period 1993 to 1999 . Table 2 provides a different look at the descriptive statistics, broken down by time period (pre-welfare reform, year of welfare reform, and postwelfare reform) and nativity (foreign born vs. native born). Table 1 shows that 3.0 percent of foreign-born individuals received SSI benefits compared with 1.6 percent of native-born individuals over the 1993 to 1999 time period. For the time periods shown in Table 2, the percentage of foreign-born individuals receiving SSI held steady at about 3.1 percent during the pre-reform period and the year of welfare reform, and then decreased to 2.9 percent during the post-reform period. The percentage of native-born individuals receiving SSI decreased steadily from 1.7 percent in the pre-reform period to 1.6 percent in the year of welfare reform and 1.5 
percent in the post-reform period. In other words, the percentage of individuals receiving SSI decreased by about 5.5 percent among foreign-born individuals between the pre-welfare reform and post-welfare reform periods, compared to a decrease of about 9.5 percent for native-born individuals over the same period.

Table 3 presents probit estimates of SSI participation for the combined native-born and foreign-born samples for the period 1993 to 1999. The first regression includes a vector of personal characteristics, a vector of state economic and policy variables, and an indicator variable to identify foreign-born individuals. The results indicate that the foreign born are significantly more likely to participate in SSI than the native born, that females are less likely to participate than males, and that older persons are less likely to participate than younger. SSI participation was also significantly greater in states with relatively high unemployment rates and relatively high poverty rates. It was lower in states that had relatively generous welfare policies toward immigrants. SSI participation fell with the implementation of the state's TANF program.

The second regression in Table 3 replaces the foreign-born indicator with a series of indicators specific to individual countries (with the native born serving as the benchmark group). With only one exception (the catchall "other" group), each foreign-born group is more likely to participate than its native-born counterpart. The countries that have contributed relatively large numbers of refugees particularly stand out. This group includes Laos, Russia, Cuba, and Vietnam.

The final regression in Table 3 focuses on entry cohorts. Those cohorts that entered the U.S. before 1960 show significantly lower probabilities of SSI participation than natives. However, those cohorts that entered the U.S. between 1960 and 1996 all had significantly higher rates of participation than natives. The fact that immigrant skills declined appreciably after 1965 
is well recognized. In 1965 (fully implemented in 1968), Congress moved away from the national origins quota system that placed more emphasis on skills (especially after 1952) and moved to an entry system based more on family reunification. The lower probability of participation for the 1997 to 1999 entry cohort could be partly due to the 1996 changes that are our focus in this paper. We explore this hypothesis more completely in the models that follow.

Table 4 repeats the models presented in Table 3, but with the sample limited to individuals with low earnings as a rough proxy for SSI income eligibility. The results are qualitatively the same as those presented for the full sample in Table 3, but the estimated coefficients are substantially larger in absolute value. Among low earners, foreign-born individuals overall and from the 12 individual countries identified in column 2 are significantly more likely than natives to participate in the SSI program. The estimates in column 3 show that immigrants who entered the U.S. before 1960 are less likely to participate than natives, as are immigrants who entered the U.S. after 1996. Those who immigrated between 1960 and 1996 are significantly more likely than natives to participate in the SSI program.

Results from the difference-in-differences models are reported in Table 5 for the full sample and in Table 6 for the low-earner sample, following the specifications in equations (2) through (4). Table 7 summarizes the difference-in-differences estimators for the relevant comparison groups. Model 1 compares the probability of SSI participation among foreign-born individuals relative to native-born individuals, after welfare reform relative to before welfare reform. The results indicate that the foreign born are more likely to participate and that the probability of participation among both the foreign born and the native born decreased after welfare reform, all else equal. The difference-in-differences term is positive and significant, indicating that the probability of SSI participation in the post-reform period increased for the 
foreign born relative to otherwise similar native-born individuals. This result is somewhat unexpected given the explicit focus of welfare reform on reducing welfare utilization among immigrants. However, this model is naïve in that it does not account for the fact that certain groups of immigrants were unaffected by welfare reform.

Model 2 makes the distinction between affected and unaffected immigrants. For this model, the sample is limited to foreign-born individuals. The results indicate that affected immigrants are significantly less likely to participate in the SSI program than otherwise similar unaffected immigrants. After controlling for the composition of immigrants between the prereform and post-reform period and differences in state economic and policy characteristics, the probability of SSI participation is higher in the post-reform period than in the pre-reform period. The difference-in-differences term is negative, indicating that relative to otherwise similar unaffected immigrants, the probability of SSI participation among affected immigrants decreased in the post-reform period. The magnitude of the effect is extremely small when the full sample of foreign-born individuals is used (Table 5). When the sample is limited to foreign-born individuals with low earnings as a rough proxy for SSI eligibility (Table 6), the difference-indifferences effect is substantially larger (-0.14 percentage points).

Models 3 and 4 add native-born individuals to the sample. Model 3 controls for affected status but not nativity, whereas model 4 includes controls for both affected status and nativity. The results for model 3 are consistent with both model 1 and model 2. The probability of SSI participation is significantly lower for affected immigrants than for unaffected individuals, which include both unaffected immigrants and native-born individuals. The probability of SSI participation decreased overall in the post-reform period. The difference-in-differences term is positive, indicating that the probability of SSI participation among affected immigrants in the 
post-reform period increased relative to unaffected individuals. This finding is largely because native-born individuals are included in the unaffected group, and their participation patterns swamp those of the much smaller group of unaffected immigrants.

Model 4 includes the measures of affected status, and adds a control variable for nativity, as well as difference-in-differences terms for native-born relative to foreign-born individuals. This is the most complete model in that it allows us to estimate three difference-in-differences effects. The basic results in Tables 5 and 6 indicate that affected immigrants are less likely to participate in SSI than unaffected immigrants and that native-born individuals are significantly less likely to participate than immigrants. The difference-in-differences effects are calculated and summarized in Table 7. Relative to unaffected immigrants, the probability of SSI participation decreased among affected immigrants in the post-reform period, confirming the results from model 2. For the low earner sample, the magnitude of that effect is -0.6 percentage points.

The probability of SSI participation for both affected immigrants and unaffected immigrants, relative to native-born individuals, increased in the post-reform period. But the magnitude of the difference-in-differences effect for affected immigrants ( 0.5 percentage points in the low earners model) is only half as large as the difference-in-differences effect for unaffected immigrants (1.1 percentage points in the low earners model). These results suggest that, although the probability of SSI participation among immigrants as a whole increased in the post-reform period relative to otherwise similar native-born individuals, the welfare reforms led to substantial reductions in the probability of SSI participation among those immigrants who were affected by the legislation (i.e., immigrants who were not receiving SSI in August, 1996, and non-refugee, non-asylee immigrants who entered the U.S. after August, 1996). 


\section{Summary and Conclusions}

Before 1996, Congress dealt with legal immigration more or less "directly" by means of a three-tier (world, country, and preference category) system of controls. Although this system remained in effect after 1996, the welfare reform policies enacted in that year introduced a new dimension in the U.S. immigrant admittance program. Now legal immigrants were limited in their eligibility for certain social programs. If immigrants were coming to the United States to enjoy various social benefits, at least some of those benefits would now be denied them.

In this paper, our specific focus is on SSI participation, and we use a unique set of administrative data to estimate a number of models of such participation. Our probit results clearly show that immigrants are more likely to participate in SSI than the native born, that females are less likely to participate than males, and that older persons are less likely to participate than younger. Immigrants who entered the U.S. between 1960 and 1996 are significantly more likely to participate than natives, whereas immigrants who entered before 1960 or after 1996 are less likely to participate than natives.

A series of difference-in-differences models suggests that the probability of SSI participation by immigrants increased in the post-welfare reform period relative to otherwise similar natives. When we identify immigrants whose potential SSI eligibility was affected by welfare reform separately from those whose potential SSI eligibility was not affected, we find that the probability of SSI participation among affected immigrants declined significantly after the implementation of welfare reform relative to unaffected immigrants. Although both groups of immigrants are significantly more likely to participate in the post-reform period than 
otherwise similar natives, it appears that the welfare reform legislation led to reductions in the probability of SSI participation among affected immigrants relative to unaffected immigrants.

This is an important finding given that the vast majority of immigrants are in the affected group with respect to potential SSI eligibility. Only those immigrants who were receiving SSI in August, 1996, or who entered the U.S. as refugees or asylees and have been in the country for seven years or less, are unaffected by the provisions of welfare reform. As time passes and new immigrants continue to enter the U.S. in large numbers, the affected group will continue to grow. To the extent that the source-country composition of new immigrants to the U.S. continues to be dominated by countries with higher propensities for welfare participation, and the skillcomposition of new immigrants continues to deteriorate, welfare reform will continue to impose strong restrictions on the welfare utilization of immigrants. On the other hand, immigrants who become naturalized U.S. citizens transition from affected to unaffected status, and thus undo some of the restrictions imposed by welfare reform. To the extent that immigrants from source countries with higher propensities for welfare participation have higher naturalization rates, this can become an important avenue for canceling out some of the impact of welfare reform. 


\section{References}

Bean, Frank D., and Jennifer V. W. Van Hook (1996-97), "Public Assistance Use by Immigrants: What Can the U.S. Census Tell Us?” Focus 18(2), Fall/Winter, 41-46.

Bean, Frank D., Jennifer V. W. Van Hook, and Jennifer E. Glick (1997), “Country of Origin, Type of Public Assistance, and Patterns of Welfare Recipiency among U.S. Immigrants and Natives," Social Science Quarterly 78(2), June, 432-451.

Blau, Francine D. (1984), “The Use of Transfer Payments by Immigrants,” Industrial and Labor Relations Review 37(2): 222-239.

Borjas, George J. (2002), "Welfare Reform and Immigrant Participation in Welfare Programs," International Migration Review 36(4): 1093-1123.

Borjas, George J., and Stephen J. Trejo (1993), "National Origin and Immigrant Welfare Recipiency," Journal of Public Economics 50(3), March, 325-344. (1991), "Immigrant Participation in the Welfare System," Industrial and Labor Relations Review 44(2): 195-211.

Council of Economic Advisors (1997). Explaining the Decline in Welfare Receipt, 1993-1996. Washington, DC: Council of Economic Advisors.

Crouse, Gil (1999). State Implementation of Major Changes to Welfare Policies, 1992-1998. Washington, DC: Department of Health and Human Services, Office of the Assistant Secretary for Planning and Evaluation.

Figlio, David N. and James P. Ziliak (1999). "Welfare Reform, the Business Cycle, and the Decline in AFDC Caseloads." In Economic Conditions and Welfare Reform, Sheldon Danziger (Ed.). Kalamazoo, MI: W.E. Upjohn Institute for Employment Research. 
Fix, Michael E. and Jeffrey S. Passel (2002). The Scope and Impact of Welfare Reform's Immigrant Provisions. Assessing the New Federalism Discussion Paper 02-03. Washington, DC: The Urban Institute.

Fix, Michael E. and Jeffrey S. Passel (1999), “Trends in Noncitizens’ and Citizens’ Use of Public Benefits Following Welfare Reform: 1994-97.” Urban Institute Research Report. Washington, DC: Urban Institute.

Greenwood, Michael J., and John M. McDowell (1999). Legal U.S. Immigration: Influences on Gender, Age, and Skill Composition. Kalamazoo, MI: W.E. Upjohn Institute for Employment Research.

Haider, Steven J., Jacob A. Klerman, and Elizabeth Roth (2003). "The Relationship Between the Economy and the Welfare Caseload: A Dynamic Approach." In Research in Labor Economics 22, Solomon Polachek, (Ed.). Amsterdam: Elsevier, JAI Press.

Moffitt, Robert A. (1999). “The Effect of Pre-PRWORA Waivers on AFDC Caseloads and Female Earnings, Income, and Labor Force Behavior.” In Economic Conditions and Welfare Reform, Sheldon Danziger (Ed.). Kalamazoo, MI: W.E. Upjohn Institute for Employment Research.

Parrott, Thomas M., Lenna D. Kennedy, and Charles G. Scott (1998), "Noncitizens and the Supplemental Security Income Program,” Social Security Bulletin 61(4): 3-31.

Social Security Administration (2003). SSI Annual Statistical Report 2002. Baltimore, MD: Social Security Administration.

Social Security Administration (1996). SSI Annual Statistical Report 1995. Baltimore, MD: Social Security Administration. 
Tienda, Marta and Leif Jensen (1986), "Immigration and Public Assistance Participation: Dispelling the Myth of Dependency," Social Science Research 15(4): 372-400.

Van Hook, Jennifer V. W., Frank D. Bean, and Jennifer E. Glick (1996), “The Development and Assessment of Census-Based Measures of AFDC and SSI Recipiency," Journal of Economic and Social Measurement 22, 1-23.

Zimmermann, Wendy and Karen C. Tumlin (1999). Patchwork Policies: State Assistance Programs for Immigrants under Welfare Reform. Occasional Paper No. 24. Washington, DC: The Urban Institute. 
Table 1: Descriptive Statistics and Variable Definitions, Foreign Born and Native Born, 1993-1999

\begin{tabular}{|c|c|c|c|c|c|}
\hline \multirow[b]{2}{*}{ Variable } & \multirow[b]{2}{*}{ Definition } & \multicolumn{2}{|c|}{ Foreign Born } & \multicolumn{2}{|c|}{ Native Born } \\
\hline & & Mean & Std Err & Mean & Std Err \\
\hline$\overline{S S I} \mathrm{CY}$ & Receipt of SSI & 0.0301 & 0.0001 & 0.0160 & 0.0001 \\
\hline SSIPMT_CY & SSI benefit (annual) & 143.7142 & 0.7624 & 56.1715 & 0.4317 \\
\hline AGE & Age & 41.1111 & 0.0122 & 41.1387 & 0.0120 \\
\hline FEMALE & Female & 0.4649 & 0.0004 & 0.4958 & 0.0004 \\
\hline TTCOMP_TH & Total annual compensation (thousands of \$) & 17.1518 & 0.0435 & 20.3014 & 0.0403 \\
\hline NJOBS & Number of jobs held in a year & 1.0996 & 0.0010 & 1.2568 & 0.0009 \\
\hline MOVED & Lived in a different state in the previous year & 0.0570 & 0.0002 & 0.0743 & 0.0002 \\
\hline FB & Foreign born & 1.0000 & 0.0000 & 0.0000 & 0.0000 \\
\hline AFFECTED & Foreign born and affected by welfare reform & 0.9371 & 0.0002 & 0.0000 & 0.0000 \\
\hline CHINA & Born in China & 0.0262 & 0.0001 & --- & --- \\
\hline CUBA & Born in Cuba & 0.0330 & 0.0001 & ---- & ---- \\
\hline DOMREP & Born in the Dominican Republic & 0.0245 & 0.0001 & --- & ---- \\
\hline INDIA & Born in India & 0.0325 & 0.0001 & ---- & ---- \\
\hline IRAN & Born in Iran & 0.0117 & 0.0001 & --- & --- \\
\hline KOREAS & Born in North Korea or South Korea & 0.0258 & 0.0001 & --- & --- \\
\hline LAOS & Born in Laos & 0.0087 & 0.0001 & ---- & ---- \\
\hline MEXICO & Born in Mexico & 0.2054 & 0.0003 & --- & --- \\
\hline PHILIP & Born in the Philippines & 0.0566 & 0.0002 & --- & ---- \\
\hline RUSSIA & Born in Russia & 0.0195 & 0.0001 & --- & ---- \\
\hline TAIWAN & Born in Taiwan & 0.0197 & 0.0001 & --- & --- \\
\hline VIETNAM & Born in Vietnam & 0.0378 & 0.0002 & ---- & ---- \\
\hline FB_OTHER & Born in a country other than those listed above & 0.4984 & 0.0004 & ---- & ---- \\
\hline ENTLE39 & Entered the U.S. before 1940 & 0.0066 & 0.0001 & --- & ---- \\
\hline ENT4049 & Entered the U.S. between 1940 and 1949 & 0.0076 & 0.0001 & ---- & ---- \\
\hline ENT5059 & Entered the U.S. between 1950 and 1959 & 0.0317 & 0.0001 & --- & --- \\
\hline ENT6069 & Entered the U.S. between 1960 and 1969 & 0.1046 & 0.0003 & ---- & ---- \\
\hline ENT7079 & Entered the U.S. between 1970 and 1979 & 0.2202 & 0.0003 & ---- & ---- \\
\hline ENT8089 & Entered the U.S. between 1980 and 1989 & 0.3729 & 0.0004 & ---- & ---- \\
\hline ENT9096 & Entered the U.S. between 1990 and 1996 & 0.2313 & 0.0003 & ---- & ---- \\
\hline ENT9799 & Entered the U.S. after 1996 & 0.0252 & 0.0001 & --- & ---- \\
\hline UR & State unemployment rate & 5.8603 & 0.0012 & 5.2966 & 0.0011 \\
\hline POV & State poverty rate & 14.8211 & 0.0030 & 13.6016 & 0.0029 \\
\hline EARNPW_TH & State earnings per worker (thousands of $\$$ ) & 37.5516 & 0.0046 & 34.9048 & 0.0045 \\
\hline GENEROÜS & Generous state welfare policies toward immigrants & 0.7431 & 0.0004 & 0.5027 & 0.0004 \\
\hline AFDCW & State AFDC waivers implemented & 0.6412 & 0.0004 & 0.5676 & 0.0004 \\
\hline TIMP & State TANF program implemented & 0.4038 & 0.0004 & 0.4260 & 0.0004 \\
\hline ATMAX3 & State maximum AFDC/TANF benefit for family of three & 460.6195 & 0.1238 & 390.8886 & 0.1151 \\
\hline SUPP & Maximum SSI state supplement & 70.8272 & 0.0610 & 37.5529 & 0.0485 \\
\hline $\mathrm{N}$ & Number of observations & 1,455 & & 1,57 & \\
\hline
\end{tabular}


Table 2: Descriptive Statistics, Foreign Born and Native Born, Pre-Welfare Reform (1993-1995), Year of Welfare Reform (1996), and Post-Welfare Reform (1997-1999)

\begin{tabular}{|c|c|c|c|c|c|c|c|c|c|c|c|c|}
\hline \multirow[b]{3}{*}{ Variable } & \multicolumn{4}{|c|}{ Pre-Welfare Reform (1993-1995) } & \multicolumn{4}{|c|}{ Year of Welfare Reform (1996) } & \multicolumn{4}{|c|}{ Post-Welfare Reform (1997-1999) } \\
\hline & \multicolumn{2}{|c|}{ Foreign Born } & \multicolumn{2}{|c|}{ Native Born } & \multicolumn{2}{|c|}{ Foreign Born } & \multicolumn{2}{|c|}{ Native Born } & \multicolumn{2}{|c|}{ Foreign Born } & \multicolumn{2}{|c|}{ Native Born } \\
\hline & Mean & Std Err & Mean & Std Err & \begin{tabular}{|l|l|} 
Mean \\
\end{tabular} & Std Err & Mean & Std Err & Mean & Std Err & Mean & Std Err \\
\hline$\overline{\text { SSI_CY }}$ & 0.0308 & 0.0002 & 0.0167 & 0.0002 & 0.0311 & 0.0004 & 0.0163 & 0.0003 & 0.0291 & 0.0002 & 0.0151 & 0.0001 \\
\hline SSIPMT_CY & 141.2995 & 1.1890 & 55.5559 & 0.6542 & 149.6986 & 2.0543 & 58.2165 & 1.1694 & 143.9128 & 1.1335 & 56.0834 & 0.6579 \\
\hline AGE & 40.2299 & 0.0192 & 40.2104 & 0.0183 & 41.0311 & 0.0323 & 41.1307 & 0.0318 & 41.8821 & 0.0181 & 41.9890 & 0.0184 \\
\hline FEMALE & 0.4666 & 0.0007 & 0.4974 & 0.0006 & 0.4657 & 0.0011 & 0.4965 & 0.0011 & 0.4633 & 0.0006 & 0.4942 & 0.0006 \\
\hline TTCOMP_TH & 15.2493 & 0.0510 & 18.8413 & 0.0477 & 16.5117 & 0.1228 & 19.9247 & 0.0936 & 18.9606 & 0.0742 & 21.7544 & 0.0728 \\
\hline NJOBS ${ }^{-}$ & 1.0791 & 0.0015 & 1.2522 & 0.0014 & 1.0887 & 0.0025 & 1.2586 & 0.0025 & 1.1203 & 0.0014 & 1.2605 & 0.0014 \\
\hline MOVED & 0.0732 & 0.0003 & 0.1018 & 0.0004 & 0.0441 & 0.0004 & 0.0528 & 0.0005 & 0.0473 & 0.0003 & 0.0559 & 0.0003 \\
\hline FB & 1.0000 & 0.0000 & 0.0000 & 0.0000 & 1.0000 & 0.0000 & 0.0000 & 0.0000 & 1.0000 & 0.0000 & 0.0000 & 0.0000 \\
\hline AFFECTED & 0.9325 & 0.0003 & 0.0000 & 0.0000 & 0.9331 & 0.0005 & 0.0000 & 0.0000 & 0.9422 & 0.0003 & 0.0000 & 0.0000 \\
\hline CHINA & 0.0251 & 0.0002 & --- & --- & 0.0263 & 0.0004 & --- & ---- & 0.0271 & 0.0002 & ---- & ---- \\
\hline CUBA & 0.0337 & 0.0002 & --- & --- & 0.0336 & 0.0004 & --- & --- & 0.0322 & 0.0002 & --- & --- \\
\hline DOMREP & 0.0241 & 0.0002 & --- & ---- & 0.0246 & 0.0003 & --- & --- & 0.0248 & 0.0002 & ---- & --- \\
\hline INDIA & 0.0303 & 0.0002 & --- & ---. & 0.0320 & 0.0004 & ---- & --- & 0.0346 & 0.0002 & ---- & --- \\
\hline IRAN & 0.0121 & 0.0001 & --- & ---. & 0.0117 & 0.0002 & ---- & --- & 0.0114 & 0.0001 & --- & --- \\
\hline KOREAS & 0.0263 & 0.0002 & --- & --- & 0.0258 & 0.0003 & --- & --- & 0.0255 & 0.0002 & --- & --- \\
\hline LAOS & 0.0090 & 0.0001 & --- & --- & 0.0087 & 0.0002 & --- & --- & 0.0084 & 0.0001 & ---- & --- \\
\hline MEXICO & 0.2089 & 0.0005 & --- & --- & 0.2050 & 0.0009 & ---- & --.- & 0.2026 & 0.0005 & --- & --- \\
\hline PHILIP & 0.0572 & 0.0003 & --.. & $-\ldots$ & 0.0569 & 0.0005 & ---- & -.- & 0.0560 & 0.0003 & |--- & --.- \\
\hline RUSSIA & 0.0199 & 0.0002 & --- & --- & 0.0198 & 0.0003 & --- & --- & 0.0191 & 0.0002 & ---- & --- \\
\hline TAIWAN & 0.0206 & 0.0002 & --- & --- & 0.0199 & 0.0003 & --- & --- & 0.0189 & 0.0002 & ---- & --- \\
\hline VIETNAM & 0.0383 & 0.0003 & --- & --- & 0.0382 & 0.0004 & ---- & $-\ldots$ & 0.0372 & 0.0002 & --- & --- \\
\hline FB_OTHER & 0.4945 & 0.0007 & --.. & $-\ldots$ & 0.4974 & 0.0011 & --- & --- & 0.5021 & 0.0006 & --- & ---- \\
\hline ENT̄LE39 & 0.0072 & 0.0001 & --- & --- & 0.0066 & 0.0002 & --- & --- & 0.0061 & 0.0001 & ---- & --- \\
\hline ENT4049 & 0.0083 & 0.0001 & --- & --- & 0.0075 & 0.0002 & --- & --- & 0.0070 & 0.0001 & ---- & --- \\
\hline ENT5059 & 0.0347 & 0.0002 & --- & --- & 0.0317 & 0.0004 & ---- & $--\cdot$ & 0.0292 & 0.0002 & --- & --- \\
\hline ENT6069 & 0.1142 & 0.0004 & --- & --- & 0.1043 & 0.0007 & --- & $--\cdot$ & 0.0965 & 0.0004 & --- & --- \\
\hline ENT7079 & 0.2391 & 0.0006 & --- & --- & 0.2198 & 0.0009 & --- & --- & 0.2042 & 0.0005 & ---- & --- \\
\hline ENT8089 & 0.3937 & 0.0006 & --- & --- & 0.3725 & 0.0011 & --- & -... & 0.3553 & 0.0006 & ---- & --- \\
\hline ENT9096 & 0.2028 & 0.0005 & --- & --- & 0.2575 & 0.0010 & --- & --- & 0.2474 & 0.0005 & --- & --- \\
\hline ENT9799 & 0.0000 & 0.0000 & --- & --- & 0.0000 & 0.0000 & --- & --- & 0.0543 & 0.0003 & --- & --- \\
\hline UR & 6.9037 & 0.0019 & 6.1310 & 0.0017 & 5.9498 & 0.0023 & 5.3563 & 0.0022 & 4.9490 & 0.0012 & 4.5157 & 0.0012 \\
\hline POV & 15.1549 & 0.0044 & 14.3406 & 0.0045 & 15.7416 & 0.0087 & 14.0196 & 0.0082 & 14.2543 & 0.0045 & 12.7940 & 0.0041 \\
\hline EARNPW_TH & 34.4749 & 0.0056 & 32.1530 & 0.0055 & 36.8335 & 0.0100 & 34.2924 & 0.0101 & 40.3790 & 0.0064 & 37.6123 & 0.0066 \\
\hline GENEROŪS & 0.7502 & 0.0006 & 0.5072 & 0.0006 & 0.7446 & 0.0010 & 0.5027 & 0.0011 & 0.7367 & 0.0005 & 0.4986 & 0.0006 \\
\hline AFDCW & 0.4311 & 0.0006 & 0.2814 & 0.0005 & 0.6905 & 0.0009 & 0.6607 & 0.0008 & 0.8041 & 0.0005 & 0.7993 & 0.0005 \\
\hline TIMP & 0.0000 & 0.0000 & 0.0000 & 0.0000 & 0.0706 & 0.0002 & 0.0975 & 0.0002 & 0.8486 & 0.0004 & 0.9194 & 0.0003 \\
\hline ATMAX3 & 466.1018 & 0.2025 & 391.3417 & 0.1825 & 462.6339 & 0.3291 & 390.2700 & 0.3033 & 455.3544 & 0.1771 & 390.6717 & 0.1699 \\
\hline SUPP & 73.6333 & 0.1003 & 39.1198 & 0.0789 & 68.7270 & 0.1540 & 36.4726 & 0.1238 & 69.0985 & 0.0881 & 36.4657 & 0.0706 \\
\hline $\mathrm{N}$ & 571,8 & & 644 & & 208,3 & & 224 & & 675,1 & & 706 & \\
\hline
\end{tabular}


Table 3: Probit Estimates of SSI Participation among the Native Born and Foreign Born, 1993-1999

\begin{tabular}{|c|c|c|c|}
\hline $\begin{array}{l}\text { Dependent } \\
\text { Variable: SSI_CY }\end{array}$ & (1) & (2) & (3) \\
\hline Independent Varia & & & \\
\hline AGE & 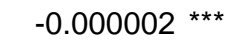 & $-0.000001 * \star \star$ & $-0.000002 * \star \star$ \\
\hline AGE2 & $0.000000 * * *$ & $0.000000 * * *$ & $0.000000 * * *$ \\
\hline FEMALE & $-0.000022 * \star * \star$ & -0.000019 ** & $-0.000024 * * \star$ \\
\hline FEMALE_AGE & 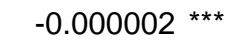 & 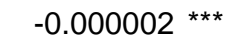 & $-0.000002 * \star \star$ \\
\hline FEMALE_AGE2 & $0.000000 * \star \star$ & $0.000000 * \star \star$ & $0.000000^{* * \star}$ \\
\hline TTCOMP_TH & $-0.000028 * \star *$ & $-0.000027 * \star \star *$ & $-0.000027 * \star \star$ \\
\hline NJOBS & $-0.000055 * * *$ & $-0.000054 * * *$ & -0.000054 *** \\
\hline MOVED & $-0.000030 * \star *$ & $-0.000029 * \star \star$ & $-0.000029 * * \star$ \\
\hline FB & $0.000067^{* \star *}$ & & \\
\hline CHINA & & $0.000255 * \star \star$ & \\
\hline CUBA & & 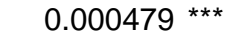 & \\
\hline DOMREP & & $0.000210 * * *$ & \\
\hline INDIA & & $0.000060 * \star *$ & \\
\hline IRAN & & $0.000266 * \star \star$ & \\
\hline KOREAS & & 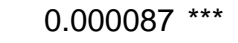 & \\
\hline LAOS & & 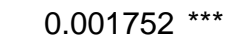 & \\
\hline MEXICO & & $0.000022 * \star \star *$ & \\
\hline PHILIP & & $0.000228 * \star *$ & \\
\hline RUSSIA & & 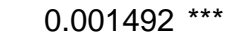 & \\
\hline TAIWAN & & $0.000103 * \star *$ & \\
\hline VIETNAM & & 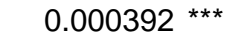 & \\
\hline FB_OTHER & & $-0.000011 * * *$ & \\
\hline ENTLE39 & & & -0.000034 ** \\
\hline ENT4049 & & & $-0.000052 * \star \star$ \\
\hline ENT5059 & & & 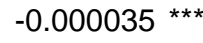 \\
\hline ENT6069 & & & $0.000040^{* * \star}$ \\
\hline ENT7079 & & & $0.000076^{* * \star}$ \\
\hline ENT8089 & & & $0.000153^{* * \star}$ \\
\hline ENT9096 & & & 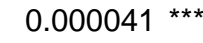 \\
\hline ENT9799 & & & $-0.000044 * \star \star$ \\
\hline UR & $0.000004^{* * *}$ & $0.000004 * * *$ & 0.000004 *** \\
\hline POV & 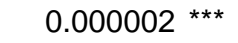 & 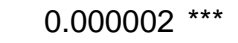 & $0.000002 * \star \star$ \\
\hline EARNPW_TH & $-0.000001 * \star \star$ & $-0.000001 * \star \star$ & $-0.000001 * \star \star$ \\
\hline GENEROUS & 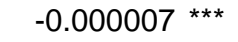 & $-0.000009 * \star \star$ & $-0.000007 * \star \star$ \\
\hline AFDCW & $0.000005^{* * *}$ & $0.000005^{* * *}$ & $0.000005 * \star \star$ \\
\hline TIMP & -0.000003 & -0.000003 & -0.000003 \\
\hline ATMAX3 & $0.000000 * \star \star$ & $0.000000 * \star *$ & $0.000000^{* * \star}$ \\
\hline SUPP & $0.000000^{* * *}$ & $0.000000 * * \star$ & $0.000000^{* * *}$ \\
\hline Observations & 3030850 & 3030850 & 3030850 \\
\hline Log L & -196256.25 & -195304.13 & -196015.3 \\
\hline Pseudo R2 & 0.2534 & 0.257 & 0.2543 \\
\hline
\end{tabular}

Coefficients have been transformed to represent marginal effects.

Year fixed effects included in all models.

* significant at 10\%; ** significant at 5\%; ** significant at $1 \%$ 
Table 4: Probit Estimates of SSI Participation among the Native Born and Foreign Born, Low Earner Sample, 1993-1999

\begin{tabular}{|c|c|c|c|}
\hline $\begin{array}{l}\text { Dependent } \\
\text { Variable: SSI_CY }\end{array}$ & (1) & $(2)$ & (3) \\
\hline \multicolumn{4}{|c|}{ Independent Variables } \\
\hline AGE & $-0.000209 \star \star \star *$ & $-0.000188 * \star \star$ & $-0.000214 * \star \star \star$ \\
\hline AGE2 & $0.000003 * * *$ & $0.000003 * * *$ & $0.000003 * \star *$ \\
\hline FEMALE & $-0.003433 * * *$ & $-0.003145 * * *$ & $-0.003696 * * *$ \\
\hline FEMALE_AGE & $-0.000264 * * *$ & $-0.000280 * * *$ & $-0.000246 * * *$ \\
\hline FEMALE_AGE2 & $0.000008 * \star *$ & $0.000008 * \star *$ & $0.000007 * \star \star$ \\
\hline TTCOMP_TH & $-0.004475 * \star \star$ & $-0.004444 * \star \star$ & $-0.004470 * \star \star$ \\
\hline NJOBS ${ }^{-}$ & $-0.006155 * * *$ & $-0.006090 * * *$ & $-0.006093 * * *$ \\
\hline MOVED & $-0.004304 * * *$ & $-0.004259 * \star *$ & $-0.004326 * \star \star *$ \\
\hline FB & $0.007942 * \star \star$ & & \\
\hline CHINA & & $0.023833 * * *$ & \\
\hline CUBA & & $0.038040 * * *$ & \\
\hline DOMREP & & $0.020343 * \star *$ & \\
\hline INDIA & & $0.007168 * \star *$ & \\
\hline IRAN & & $0.024467 * \star *$ & \\
\hline KOREAS & & $0.009862 * * *$ & \\
\hline LAOS & & $0.090102 * \star \star$ & \\
\hline MEXICO & & $0.002952 * * *$ & \\
\hline PHILIP & & $0.021807 * * *$ & \\
\hline RUSSIA & & 0.080256 *** & \\
\hline TAIWAN & & $0.011522 * * *$ & \\
\hline VIETNAM & & $0.032688 * \star *$ & \\
\hline FB_OTHER & & $-0.001493 * \star *$ & \\
\hline ENT̄LE39 & & & $-0.005025 * \star$ \\
\hline ENT4049 & & & $-0.008658 * * *$ \\
\hline ENT5059 & & & $-0.005240 * * *$ \\
\hline ENT6069 & & & $0.004840 * * *$ \\
\hline ENT7079 & & & $0.008799 * * \star$ \\
\hline ENT8089 & & & $0.016062 * \star *$ \\
\hline ENT9096 & & & $0.005200 * * *$ \\
\hline ENT9799 & & & $-0.006710 * * *$ \\
\hline UR & $0.000578 * \star \star *$ & $0.000572 * \star *$ & $0.000548 * \star *$ \\
\hline POV & $0.000312 * * *$ & $0.000299 * \star \star$ & $0.000310^{* * *}$ \\
\hline EARNPW_TH & $-0.000169 * \star \star *$ & $-0.000142 * \star *$ & $-0.000164 * * *$ \\
\hline GENEROŪS & $-0.001027 * \star \star *$ & $-0.001337 * \star *$ & $-0.001023 * * *$ \\
\hline AFDCW & $0.000649 * * *$ & $0.000641 * \star *$ & 0.000573 *** \\
\hline TIMP & -0.000255 & -0.000299 & -0.000235 \\
\hline ATMAX3 & -0.000006 *** & $-0.000007 * \star * *$ & -0.000006 *** \\
\hline SUPP & $0.000017 * * *$ & $0.000017^{* \star *}$ & 0.000016 *** \\
\hline Observations & 1615311 & 1615311 & 1615311 \\
\hline $\log \mathrm{L}$ & -205407.14 & -204394.93 & -205147.99 \\
\hline Pseudo R2 & 0.1425 & 0.1467 & 0.1436 \\
\hline
\end{tabular}

Coefficients have been transformed to represent marginal effects.

Year fixed effects included in all models.

* significant at $10 \%$; ${ }^{\star *}$ significant at $5 \%$; ${ }^{\star \star *}$ significant at $1 \%$ 
Table 5: Probit Models of SSI Participation, Difference in Difference Estimates

\begin{tabular}{|c|c|c|c|c|}
\hline $\begin{array}{l}\text { Dependent } \\
\text { Variable: SSI_CY }\end{array}$ & $(1)$ & $(2)$ & (3) & (4) \\
\hline Model & $\begin{array}{r}\text { Foreign born vs. } \\
\text { native born, no } \\
\text { controls for affected } \\
\text { status }\end{array}$ & $\begin{array}{r}\text { Foreign born only, } \\
\text { affected vs. } \\
\text { unaffected }\end{array}$ & $\begin{array}{r}\text { Affected vs. } \\
\text { unaffected, no } \\
\text { controls for foreign } \\
\text { born vs. native born }\end{array}$ & $\begin{array}{r}\text { Affected vs. } \\
\text { unaffected with } \\
\text { controls for foreign } \\
\text { born vs. native born }\end{array}$ \\
\hline Independent Variables & & & & \\
\hline AGE & $-0.000001 * \star *$ & $0.000001 * * *$ & $-0.000001 * * *$ & 0.000000 \\
\hline AGE2 & $0.000000 * \star *$ & $0.000000 * \star$ & $0.000000 * * *$ & 0.000000 ** \\
\hline FEMALE & $-0.000021 * \star$ & $-0.000009 * * *$ & $-0.000021 * \star *$ & -0.000005 \\
\hline FEMALE_AGE & $-0.000002 * * *$ & $0.000000 *$ & $-0.000002 * \star *$ & $-0.000002 * \star *$ \\
\hline FEMALE_AGE2 & $0.000000 * * *$ & 0.000000 & $0.000000 * * *$ & $0.000000 * * *$ \\
\hline TTCOMP_TH & $-0.000025 * \star \star$ & $-0.000003 * \star *$ & $-0.000024 * \star *$ & $-0.000019 * \star \star$ \\
\hline NJOBS & $-0.000048 * \star \star$ & $-0.000007 * \star *$ & $-0.000049 * * *$ & $-0.000036 * \star \star$ \\
\hline MOVED & $-0.000029 * \star \star$ & 0.000004 ** & $-0.000029 * \star \star$ & $-0.000022 * \star \star$ \\
\hline AFFECTED & & $-0.012525 * * *$ & $-0.000078 * \star *$ & $-0.000098 * \star \star$ \\
\hline NB & & & & $-0.006070 * * *$ \\
\hline FB & $0.000044 * * *$ & & & \\
\hline POSTWR & -0.000006 & $0.000003 * \star *$ & -0.000003 & $0.000056 * \star \star$ \\
\hline POSTWR_AFFECTED & & -0.000008 *** & $0.000030 * * *$ & $-0.000029 * * *$ \\
\hline POSTWR_NB & & & & $-0.000063 * \star \star$ \\
\hline FB_POSTWR & $0.000022 * * *$ & & & \\
\hline UR & $0.000005 * * *$ & 0.000000 & $0.000005 * * *$ & $0.000003 * \star \star *$ \\
\hline POV & $0.000002 * * *$ & $0.000000 * * *$ & 0.000003 *** & 0.000001 *** \\
\hline EARNPW_TH & $-0.000001 * \star *$ & $0.000000 * * *$ & $0.000000 * *$ & $-0.000001 * \star *$ \\
\hline GENEROŪS & $-0.000007 * \star \star$ & 0.000000 & 0.000001 & -0.000008 *** \\
\hline AFDCW & $0.000005 * \star \star$ & -0.000001 ** & $0.000009 * * *$ & 0.000002 ** \\
\hline TIMP & -0.000001 & -0.000001 & -0.000004 & 0.000001 \\
\hline ATMAX3 & $0.000000 * * *$ & 0.000000 & $0.000000 * * *$ & $0.000000 * \star \star *$ \\
\hline SUPP & $0.000000 * * *$ & $0.000000 * \star *$ & $0.000000 * * *$ & $0.000000 * \star \star *$ \\
\hline Observations & $2,597,994$ & $1,246,952$ & $2,597,994$ & $2,597,994$ \\
\hline $\log L$ & & & & \\
\hline Pseudo R2 & 0.2539 & 0.6894 & 0.2620 & 0.2985 \\
\hline
\end{tabular}

The pre-reform period covers 1993-1995. The post reform period covers 1997-1999. Coefficients have been transformed to represent marginal effects.

Year fixed effects included in all models.

* significant at 10\%; ** significant at $5 \%$; *** significant at $1 \%$ 
Table 6: Probit Models of SSI Participation, Difference in Difference Estimates, Low Earners

\begin{tabular}{|c|c|c|c|c|}
\hline $\begin{array}{l}\text { Dependent } \\
\text { Variable: SSI_CY }\end{array}$ & $(1)$ & $(2)$ & (3) & (4) \\
\hline Model & $\begin{array}{r}\text { Foreign born vs. } \\
\text { native born, no } \\
\text { controls for affected } \\
\text { status }\end{array}$ & $\begin{array}{r}\text { Foreign born only, } \\
\text { affected vs. } \\
\text { unaffected }\end{array}$ & $\begin{array}{r}\text { Affected vs. } \\
\text { unaffected, no } \\
\text { controls for foreign } \\
\text { born vs. native born }\end{array}$ & $\begin{array}{r}\text { Affected vs. } \\
\text { unaffected with } \\
\text { controls for foreign } \\
\text { born vs. native born }\end{array}$ \\
\hline Independent Variables & & & & \\
\hline AGE & $-0.000210 * \star *$ & $0.000194 * * *$ & $-0.000178 * * *$ & $-0.000065 *$ \\
\hline AGE2 & $0.000003 * \star *$ & $0.000000 * * *$ & $0.000003 * \star *$ & $0.000001 * \star *$ \\
\hline FEMALE & $-0.003504 * \star \star$ & $-0.001544 * * *$ & $-0.003516 * \star *$ & -0.001166 \\
\hline FEMALE_AGE & $-0.000253 * \star *$ & 0.000021 & $-0.000249 * \star *$ & $-0.000341 * \star \star$ \\
\hline FEMALE_AGE2 & $0.000008 * \star *$ & 0.000000 & $0.000007 * * *$ & $0.000008 * \star \star$ \\
\hline TTCOMP_TH & $-0.004507 \star \star \star$ & $-0.000589 * \star \star$ & $-0.004175 * \star *$ & $-0.004068 * \star \star$ \\
\hline NJOBS & $-0.005895 * \star \star$ & $-0.001093 * \star *$ & $-0.005967 * \star \star$ & $-0.005303 * \star *$ \\
\hline MOVED & $-0.004753 * \star \star *$ & 0.000802 *** & $-0.004602 * \star \star *$ & $-0.004257 * \star \star$ \\
\hline AFFECTED & & $-0.194425 * \star *$ & $-0.015153 * \star *$ & $-0.021722 * \star \star$ \\
\hline NB & & & & $-0.195265 * \star *$ \\
\hline FB & $0.005976 * \star \star *$ & & & \\
\hline POSTWR & $-0.001036 *$ & $0.000516 * * *$ & -0.000658 & $0.009760 * \star *$ \\
\hline POSTWR_AFFECTED & & -0.001441 *** & $0.004063 * * *$ & $-0.006010 * * *$ \\
\hline POSTWR_NB & & & & $-0.011014 * \star \star$ \\
\hline FB_POSTWR & $0.003087 * * \star$ & & & \\
\hline UR & $0.000666 * * *$ & -0.000024 & 0.000748 *** & 0.000568 *** \\
\hline POV & $0.000298 * \star *$ & $0.000064 * * *$ & $0.000439 * * *$ & $0.000244 * * *$ \\
\hline EARNPW_TH & $-0.000164 * \star *$ & $0.000017 * *$ & $-0.000061 * * *$ & $-0.000096 * \star *$ \\
\hline GENEROŪS & $-0.001088 * \star \star$ & 0.000074 & 0.000033 & -0.001437 *** \\
\hline AFDCW & $0.000686 * \star \star$ & -0.000151 ** & $0.001238 * \star *$ & 0.000340 * \\
\hline TIMP & 0.000035 & -0.000145 & -0.000381 & 0.000294 \\
\hline ATMAX3 & $-0.000006 * \star \star$ & 0.000000 & $-0.000005 * \star *$ & -0.000006 *** \\
\hline SUPP & $0.000017 * \star *$ & $0.000004 * \star *$ & $0.000018 * \star *$ & 0.000013 *** \\
\hline Observations & $1,381,433$ & 712,493 & $1,381,433$ & $1,381,433$ \\
\hline $\log \mathrm{L}$ & & & & \\
\hline Pseudo R2 & 0.1427 & 0.6505 & 0.1520 & 0.1945 \\
\hline
\end{tabular}

The pre-reform period covers 1993-1995. The post reform period covers 1997-1999. Coefficients have been transformed to represent marginal effects.

Year fixed effects included in all models.

* significant at $10 \%$; ** significant at $5 \%$; *** significant at $1 \%$ 
Table 7: Summary of Difference-in-Difference Estimates

Model

Comparison groups

Difference-in-difference

estimate (\%)

\section{All individuals}

1 Foreign born vs. native born, no

Foreign born vs. native born

0.0022

controls for affected status

2 Foreign born only, affected vs. Affected vs. unaffected foreign born

$-0.0008$ unaffected

3 Affected vs. unaffected, no controls for Affected vs. unaffected foreign born

0.0030 foreign born vs. native born and native born

4 Affected vs. unaffected with controls

Affected vs. unaffected foreign born

$-0.0029$ for foreign born vs. native born

4 Affected vs. unaffected with controls for foreign born vs. native born

4 Affected vs. unaffected with controls Unaffected foreign born vs. for foreign born vs. native born unaffected native born

\section{Low Earners}

1 Foreign born vs. native born, no

Foreign born vs. native born

0.3087 controls for affected status

2 Foreign born only, affected vs. Affected vs. unaffected foreign born unaffected

3 Affected vs. unaffected, no controls for Affected vs. unaffected foreign born

0.4063 foreign born vs. native born and native born

4 Affected vs. unaffected with controls

Affected vs. unaffected foreign born

$-0.6010$ for foreign born vs. native born

4 Affected vs. unaffected with controls for foreign born vs. native born

4 Affected vs. unaffected with controls for foreign born vs. native born

$\begin{array}{ll}\text { Affected vs. native born } & 0.5004\end{array}$

Unaffected foreign born vs. $\quad 1.1014$ unaffected native born 